\title{
Failure to Wean Caused by Cryptogenic Fibrosing Pleuritis and Bilateral Lung Trapping. Case Report ${ }^{\star}$
}

\author{
Falência do Desmame em Paciente com Fibrose Pleural \\ Idiopática e Trapping Pulmonar Bilateral. Relato de Caso
}

Elsemiek Verweel', Jos le Noble, PhD' ${ }^{1}$, Christine Groeninx-van Zoelen', Alex Maat ${ }^{2}$, Willy Thijsse ${ }^{1}$, Patricia Gerritsen ${ }^{1}$, Jan Bakker, PhD ${ }^{3}$

\section{RESUMO}

JUSTIFICATIVA E OBJETIVOS: Fibrose pleural idiopática é uma doença rara e pode afetar ambos pulmões já desde uma idade precoce. $\mathrm{O}$ achado mais comum na fibrose pleural idiopática é uma restrição pulmonar grave que pode levar a um quadro de falência respiratória e hipoxemia.

RELATO DO CASO: Paciente do sexo masculino, 26 anos, internado com reagudização de insuficiência respiratória crônica e submetido à ventilação mecânica prolongada. Após intensa investigação e uma apresentação clínica atípica, foi estabelecido o diagnóstico de fibrose pleural idiopática associado à fibrose pulmonar.

CONCLUSÕES: O prognóstico de pacientes com fibrose pleural idiopática é extremamente ruim, particularmente em fase avançada da doença. Recomenda-se o tratamento precoce com corticosteróides ou decorticação pleural cirúrgica.

\footnotetext{
1. Médica Assistente do Departamento de Terapia Intensiva

2. Médico Assistente do Departamento de Cirurgia Torácica

3. Médico Chefe do Departamento de Terapia Intensiva
}

${ }^{*}$ Received from Department of Intensive Care, Department of Pulmonary Medicine and Cardiovascular Centre Rotterdam Erasmus Medical Centre, Location Dijkzigt

Presented in August, 23, 2007

Accepted in October, 08, 2007

Author for correspondence:

Jos le Noble, M.D. PhD

Department of Intensive Care, H-620

Erasmus Medical Centre, Location Dijkzigt

Dr. Molewaterplein 50

3015 GD Rotterdam, the Netherlands

Phone: +31 630097795

E-mail: I.lenoble@erasmusmc.nl

(C)Associação de Medicina Intensiva Brasileira, 2007
Unitermos: decorticação pleural, fibrose pleural, fibrose pulmonar, Fibrotórax Idiopático.

\section{SUMMARY}

BACKGROUND AND OBJECTIVES: Cryptogenic fibrosing pleuritis is an extremely rare disease, which can affect both lungs from a very young age. The most common finding is severe lung restriction resulting in both hypoxemic and ventilatory failure.

CASE REPORT: Male patient, 26 year old with acute deterioration of chronic respiratory failure. Following admission prolonged mechanical ventilation was necessary. An atypical clinical presentation made the diagnosis difficult, but eventually cryptogenic fibrosing pleuritis and lung fibrosis were established.

CONCLUSIONS: The prognostic outcome of patients with the final diagnosis of cryptogenic fibrosing pleuritis is extremely poor, especially in an advanced phase of this disease. We recommend early treatment with corticosteroids or surgical pleural decortication.

Key Words: cryptogenic, Fibrothorax, lungfibrosis, pleural decortication, pleural fibrosis.

\section{INTRODUCTION}

Fibrothorax is usually associated with bacterial, fungal or tuberculosis infection, asbestos exposure, vasculitis or exposure to specific drugs. However, a primary cause is not always obvious. This has led to a relatively new entity, cryptogenic fibrosing pleuritis. This syndrome was first described in 1988 by Buchanan et al. ${ }^{1}$. Cryptogenic fibrosing pleuritis is characterized by pleural thickening and may be accompanied by lung fibrosis and parenchymal disease. In addition, severe thoracic -deformities may lead to severe lung restriction and impairment of lung function. 
We report the clinical course and outcome of a patient admitted to our ICU with respiratory failure in whom the diagnosis was cryptogenic fibrosing pleuritis and lung fibrosis. We discuss the importance of recognizing this rare syndrome at an early stage as treatment with corticosteroids or surgical decortication could prevent development of respiratory failure and may increase life-expectancy.

\section{CASE REPORT}

A 26-year old male was admitted to the ICU because of type 2 respiratory failure requiring mechanical ventilation.

The medical history revealed a gradual psychomotor retardation. The family history was non-contributory and the patient had no siblings. There was no consanguinity. As a child a discrepancy between length and skull circumference has been noted. A hydrocephalus was absent. Our patient did not smoke and there was no history of chronic obstructive pulmonary disease. His first symptoms were revealed in 2002 when he complained of fatigue and dyspnoea following mild exercise. A pleural effusion was present. Laboratory findings were not helpful in establishing the diagnosis and analysis of the pleural fluid did not reveal tumor cells. Blood cultures, anti-DNA antibody, anti-cardiolipine antibody and tests for tuberculosis were all negative. At that time, a biopsy of the pleura parietalis did reveal inflammation with fibrosis without signs of asbestosis. Despite symptomatic treatment with diuretics and bronchodilators the dyspnoea gradually worsened. No systemic steroids were prescribed. In 2004 he was referred to our hospital for re-evaluation of the disease and further treatment. Because of macrocephaly, severe kyphoscoliosis and enlargement of the ascending aorta ( $\varnothing 50 \mathrm{~mm}$ ) genetic screening was performed, but no known genetic syndromes were found. However, during the work-up the patient's condition deteriorated. In January 2005 blood gas analysis showed: $\mathrm{pH} 7.42, \mathrm{pCO}_{2} 7.0 \mathrm{kPa}, \mathrm{pO}_{2} 8.3 \mathrm{kPa}, \mathrm{BE}+8 \mathrm{mmol} / \mathrm{L}$, $\mathrm{SatO}_{2}$ 91\%. Lung function: VC 0.58 I (12\%), FEV1 0.49 I (13\%) and FEV1/ VC 84\% (102\%), compatible with severe restriction. A computer tomography (CT) scan showed severe entrapment of the right lung and to a lesser extent of the left lung without evidence of pulmonary fibrosis. The outpatient clinic physicians prescribed steroids in a low dose (10 mg/day). The patient continued his work as lift truck operator.

\section{Admission}

In June 2005 the patient was admitted to the ICU because of progressive respiratory failure. Physical examination revealed a frail young man with respiratory distress with a respiratory rate of 30-40 breaths per minute. Body weight was $53 \mathrm{~kg}$ and length $175 \mathrm{~cm}$. Vital signs revealed a blood pressure of $110 / 60 \mathrm{mmHg}$, a pulse of 66 beats/min. His neck veins were engorged. On inspection macrocephaly, high palate, and an abnormal thorax with evidence of a kyphoscoliosis and dystrophic appearance were seen. Auscultation of the lungs revealed bilateral coarse crackles and rhonchi, cardiovascular examination revealed a right-sided cardiac impulse, and no abnormal murmurs were heard. Abdominal examination was unremarkable except a slightly enlarged liver. The lower extremities showed no (lymph) oedema. On neurological examination there was no muscle weakness, focal deficits or other abnormalities. Blood gas analysis showed: $\mathrm{pH} 7.46$, $\mathrm{pCO}_{2} 7.0 \mathrm{kPa}, \mathrm{pO}_{2} 9.5 \mathrm{kPa}$. High dose steroids were started ( $1 \mathrm{mg} / \mathrm{kg} /$ day) because of clinical suspicion of pulmonary fibrosis.

On day 2 mechanical ventilation was required because of carbon dioxide retention due to progressive exhaustion of the patient $\left(\mathrm{pH} 7.16, \mathrm{pCO}_{2} 16.2 \mathrm{kPa}\right.$, $\mathrm{pO}_{2} 9.5 \mathrm{kPa}$ ). The patient received pressure controlled mechanical ventilation after intubation with an expiratory tidal volume (VT) of $300 \mathrm{ml}(5.7 \mathrm{~mL} / \mathrm{kg})$, a respiration rate of 20 breaths/min and with an initial positive end-expiratory pressure (PEEP) setting of 5 $\mathrm{CmH}_{2} \mathrm{O}$. Peak inspiratory pressure and plateau pressure were 30 and $18 \mathrm{mmHg}$ respectively. Fraction of inspired oxygen $\left(\mathrm{FiO}_{2}\right)$ was weaned down to 0.6, and inspiration-expiration (I:E) ratio adjusted to $1: 1$. Lungs were poorly compliant, (calculated) dynamic and static compliance were 12 and $23 \mathrm{ml} / \mathrm{kPa}$ respectively.

Blood gas analyses showed $\mathrm{pH} 7.37, \mathrm{pCO}_{2} 8.4$ $\mathrm{kPa}$ and $\mathrm{pO}_{2} 14.6 \mathrm{kPa}$ after initiation of mechanical ventilation. Chest radiography (Figure 1) showed increased markings in all lung fields, a density on the right side without signs of cardiomegaly and in addition bilateral effusions predominantly on the right hand side. A CT scan of the thorax (Figure 2) showed bilateral pleural thickening and effusions. Lung parenchyma showed areas of patchy infiltrates and progression of sub pleural atelectasis, due to pulmonary fibrosis which were not present in 2004. 


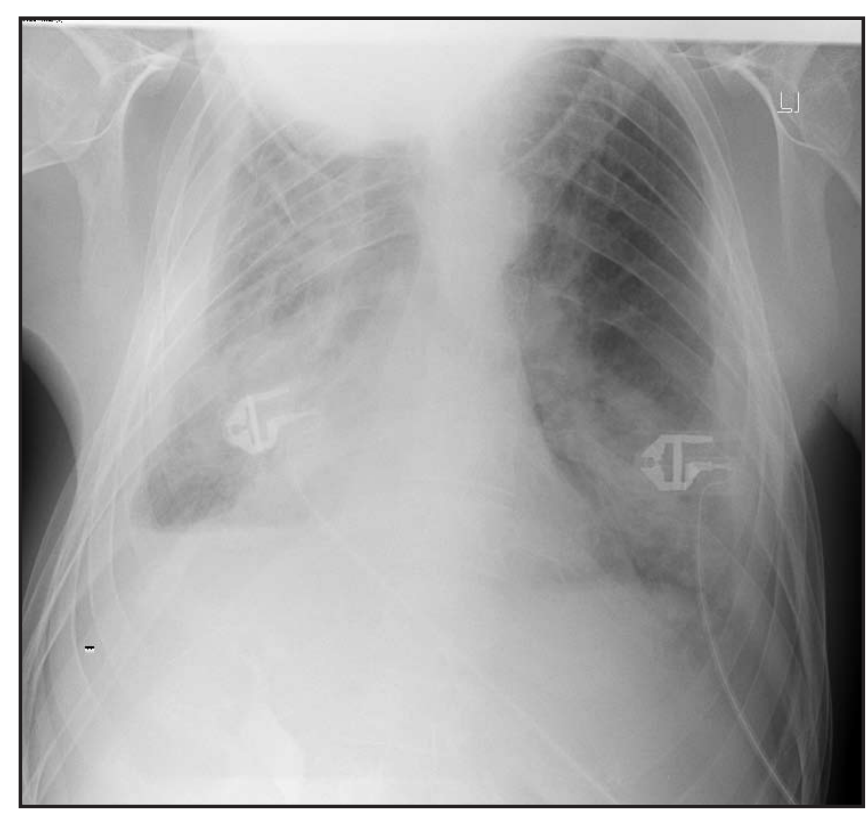

Figure 1 - X-Thorax on Day of Admittance to the ICU

Chest radiograph showing increased markings in all lung fields, a density on the right side without signs of cardiomegaly and in addition bilateral pleural thickening with effusions most prominent on the right side.

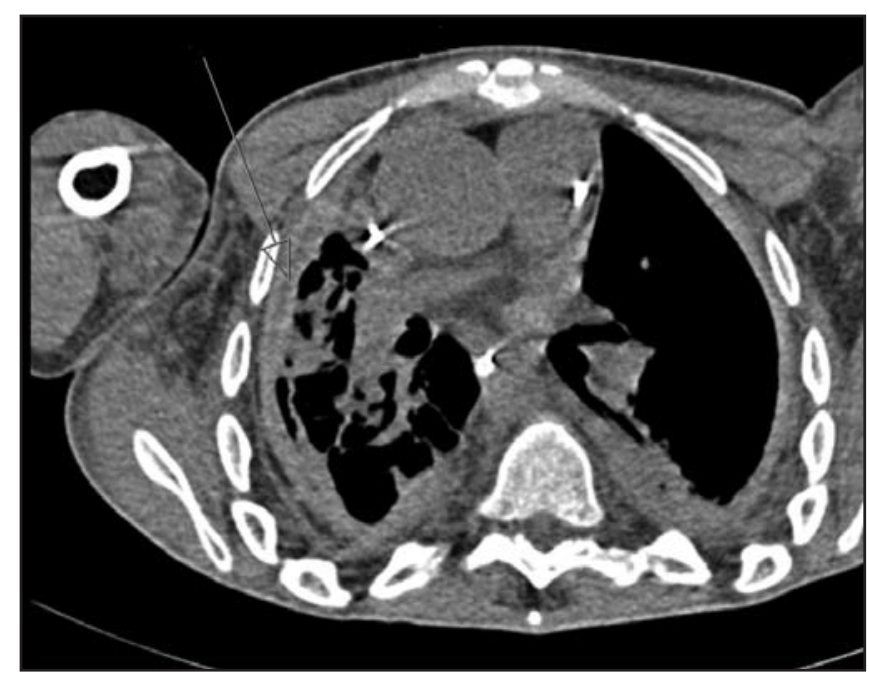

Figure 2 - CT Scan of the Thoracic Cavity

Computed tomography of the thorax demonstrating bilateral pleural thickening and effusions (arrow). Lung parenchyma showed areas of patchy infiltrates and progression of sub pleural atelectasis, due to pulmonary fibrosis.

Echocardiography of the heart revealed dilatation of the aorta ascendens $(50 \mathrm{~mm})$, tricuspid incompetence without signs of restrictive cardiomyopathy or valvular vegetations. Laboratory examination: Sodium 140 $\mathrm{mmol} / \mathrm{L}$, potassium $5.2 \mathrm{mmol} / \mathrm{L}$, calcium $2.37 \mathrm{mmol} / \mathrm{L}$, bilirubin $8 \mathrm{umol} / \mathrm{L}$, LD $222 \mathrm{U} / \mathrm{L}$, ureum $4.9 \mathrm{mmol} / \mathrm{L}$, creatinine $54 \mathrm{umol} / \mathrm{L}$, glucose $5.6 \mathrm{mmol} / \mathrm{L}$, hemoglobin 9.1 $\mathrm{mmol} / \mathrm{L}$, hematocrit $0.48 \mathrm{I} / \mathrm{L}$, platelets $40010 \mathrm{E} 9 / \mathrm{l}, \mathrm{WBC}$ 9.3 10E9/l, CRP $69 \mathrm{mg} / \mathrm{L}$. Insertion of a pulmonary artery catheter revealed: Pulmonary artery pressures of 47/33 (23) $\mathrm{mmHg}$, CVP $15 \mathrm{mmHg}$, cardiac index 4.6 $\mathrm{L} / \mathrm{min} / \mathrm{m}^{2}$ and pulmonary artery occlusion pressure (PAOP) $19 \mathrm{mmHg}$.

Pleural decortication was planned. After induction of anesthesia and positioning of the patient in left lateral position it was extremely difficult to ventilate the patient adequately. A mini right-sided thoracotomy was made. Due to the roofing-tile position of the ribs it was not possible to reach the pleura through an intercostal space. Two ribs were partially resected. A full thickness quadrangular specimen of pleura was resected and we noticed that adhesions between pleura and lung were so extensive that a serious attempt to decorticate the whole lung would result in massive blood loss. Given these problems pleural decortication was considered impossible. The full thickness biopsy of the pleura showed extended fibrotic tissue with focal reactive mesothelium. There were no signs of mesothelioma. Our patient died despite full supportive treatment on day 14 due to ventilator associated pneumonia with sepsis. Permission for autopsy was refused by the parents.

\section{Final Diagnosis}

Respiratory failure due to cryptogenic fibrosing pleuritis (fibrothorax), lungfibrosis and bilateral lung trapping complicated by a ventilator associated pneumonia with sepsis.

\section{DISCUSSION}

Respiratory failure in patients with fibrothorax is clinically characterized by fibrosing pleuritis, bilateral lung trapping and parenchymal disease. It encompasses a broad spectrum of diagnostic possibilities, which include empyema (bacterial, tubercular or fungal infections) and non-infectious causes such as hemothorax, autoimmune disease, medication or asbestos exposure. In most patients a primary cause can be established ${ }^{1,2}$. There are few cases of fibrothorax with persistent pleural effusions such as a yellow nail syndrome or lymphangiectasis ${ }^{3}$.

However, in a very small subset of patients no primary cause can be established despite thorough clinical and laboratory investigations, as was the case in our patient. In a landmark article published by Buchanan et al. in $1988^{1}$ he described 4 patients with similar clinical symptomatology as our patient for which he intro- 
duced the term cryptogenic fibrosing pleuritis. Our patient showed typical roentgenographic findings without history of trauma or infection. Radiologically, a peel of uniform thickness surrounded both lungs as well as extensive parenchymal involvement. Routine pulmonary functions test revealed a severe restrictive ventilatory dysfunction. Cryptogenic fibrosing pleuritis is classified as a form of idiopathic lung disease based on histological appearance, which may exist as an idiopathic non-malignant entity. Cryptogenic fibrosing pleuritis may typically present at an early age, however it can present at any age. In our patient histological biopsy of the pleura showed inflammatory disease through deposition of fibrous tissue on the visceral pleural surface without signs of asbestosis or granulomas resulting in the diagnosis of cryptogenic fibrosing pleuritis. The volume of the involved right sided hemithorax was diminished and in our patient respiratory failure with carbon dioxide retention developed for which mechanical ventilation was necessary. Since 1988 less than 10 articles have been published dealing with patients with similar clinical presentations of cryptogenic fibrosing pleuritis. There has been a renewed interest in this disease due to its recognized association with several metabolic diseases ${ }^{4}$.

Our patient did not have obvious metabolic abnormalities as has been described by Hayes et al. ${ }^{4}$, but also died at young age. In addition patients with cryptogenic fibrosing pleuritis may have an increased incidence of histocompatibility antigen HLA B44 $4^{1,4}$ which predisposes for congenital abnormalities. Although there was clinical suspicion in our patient for congenital abnormality this could not be confirmed by genetic consultation.

The pathogenesis of pleural fibrosis and abnormal pleural space remodeling is incompletely understood. Data suggest a primary role for the visceral pleura during the development of pleural fibrosis ${ }^{5}$. Changes in the formation of fibrinous intrapleural matrix may be the key feature in the development of respiratory impairment. Cytokines (TGF-beta and TNF-alpha) facilitate fibrin matrix formation and could be therapeutically influenced by corticosteroids 5 .

Although the number of patients with cryptogenic fibrosing pleuritis treated with corticosteroids described in the literature is small, the disease may undergo remission following immunosuppressive therapy ${ }^{1,6}$. Our patient with an advanced phase of the disease did not show any remission despite treatment with high dose corticosteroids. It cannot be excluded that treatment in a very early phase with high dose corticosteroids or the addition of azathioprine would have any beneficial effect on prognosis. Impairment in the manifestations of cryptogenic fibrosing pleuritis can furthermore be achieved by surgical treatment, but because decortication is a major surgical procedure it should not be performed in patients debilitated by other disease ${ }^{1,7,8}$. One major condition to perform this surgery is that there is a plane separating the visceral pleura from the adjacent lung. ${ }^{8}$. Our patient showed extensive pleural thickening, parenchymal disease in an advanced stage and severe deformation of the thorax making a surgical decortication technically not feasible.

Successful lung allograft transplantation in a patient with bilateral pleural fibrosis has only been reported by Azoulay et al. ${ }^{9}$. Due to progressive clinical deterioration of our patient lung transplantation was not a serious therapeutic option.

Once all clinical hallmarks of cryptogenic fibrosing pleuritis are present and a critically ill patient is admitted to the ICU for mechanical ventilation the prognosis deteriorates. If in doubt about the exact diagnosis a pleural biopsy is warranted. Treatment with high dose corticosteroids or surgical exploration proved to be ineffective and not feasible in our patient. Several attempts to wean the patient from the ventilator were unsuccessful. Spontaneous ventilation aggravated respiratory failure due to chest wall and parenchymal disease, indicating increased work of breathing.

Based on our observations, patients with cryptogenic fibrosing pleuritis should be aggressively treated with corticosteroids in an early phase of the disease on an outpatient basis. Surgical decortication of pleural fibrous tissue should be considered once ventilatory function decreases in combination with clinical symptomatology and exertional dyspnea. The prognostic outcome of patients with the final diagnosis of cryptogenic fibrosing pleuritis is extremely poor, especially in an advanced phase of this disease.

\section{Abbreviation list}

$\begin{array}{ll}\mathrm{BE} & \text { Base excess } \\ \mathrm{CBF} & \text { Cryptogenic fibrosing pleuritis } \\ \mathrm{Cm} & \text { Centimeter } \\ \mathrm{CT}-\mathrm{scan} & \text { Computer tomography scan } \\ \mathrm{CVP} & \text { Central venous pressure } \\ \mathrm{FEV} 1 & \text { Forced expiratory volume (in 1 second) } \\ \mathrm{FiO}_{2} & \text { Fractional concentration of inspired oxygen } \\ \mathrm{ICU}^{2} & \text { Intensive Care Unit } \\ \mathrm{L} & \text { Liter }\end{array}$




$\begin{array}{ll}\text { Mg } & \text { Milligram } \\ \text { Min } & \text { Minute } \\ \text { MI } & \text { Milliliter } \\ \text { Mm } & \text { Millimeter } \\ \text { Mmol } & \text { Millimol } \\ \text { PEEP } & \text { Positive end-expiratory pressure } \\ \text { PAOP } & \text { Pulmonary artery occlusion pressure } \\ \text { Sat. } & \text { Saturation } \\ \text { TGF } & \text { Tumor growth factor } \\ \text { TNF } & \text { Tumor necrosis factor } \\ \text { Umol } & \text { Micromol } \\ \text { VC } & \text { Vital capacity } \\ \text { VT } & \text { Tidal volume }\end{array}$

\section{REFERENCES}

01. Buchanan DR, Johnston ID, Kerr IH et al - Cryptogenic bilateral fibrosing pleuritis. Br J Dis Chest, 1988;82:186-193.

02. Ghoshal AG, Saha AK, Roy DJ et al - Fibrothorax--problem, profile and prevention. J Indian Med Assoc, 1997;95:610-612.

03. Cohen M, Sahn SA - Resolution of pleural effusions. Chest, 2001;119:1547-1562.

04. Hayes JP, Wiggins J, Ward K et al - Familial cryptogenic fibrosing pleuritis with Fanconi's syndrome (renal tubular acidosis). A new syndrome. Chest, 1995;107:576-578.

05. Huggins JT, Sahn SA - Causes and management of pleural fibrosis. Respirology, 2004;9:441-447.

06. O'Connor TM, Haider W, Crotty T et al - Immunosuppressant-responsive idiopathic lymphocytic pleuritis. Respiration, 2005;72:202-204.

07. Sharma S, Smith R, Al-Hameed F - Fibrothorax and severe lung restriction secondary to lupus pleuritis and its successful treatment by pleurectomy. Can Respir J, 2002;9:335-337.

08. Baram D, Degene A, Amin M et al - A case of hypercapnic respiratory failure. Chest, 2004;126: 1994-1999.

09. Azoulay E, Paugam B, Heymann MF et al - Familial extensive idiopathic bilateral pleural fibrosis. Eur Respir J, 1999;14:971-973. 